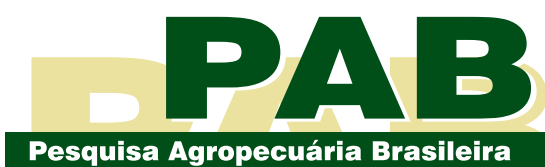

ISSN 1678-3921

Journal homepage: www.embrapa.br/pab

For manuscript submission and journal contents, access: www.scielo.br/pab

\section{Contents of total phenolics and flavonoids in and antioxidant activity of Ilex paraguariensis leaves}

\begin{abstract}
The objective of this work was to evaluate different solvents and times in the ultrasound-assisted extraction of polyphenols, in order to quantify the total phenolic and flavonoid contents in and the antioxidant activity of mate (Ilex paraguariensis) leaves. The experiment was carried out in a completely randomized design, in a $8 \times 3$ (solvent $\mathrm{x}$ time of extraction) factorial arrangement. The solvent extractors were distilled water and aqueous solutions of ethanol, acetone, and methanol, acidified or not with hydrochloric acid, and the time of ultrasound-assisted extractions were 15, 30, and $45 \mathrm{~min}$. All extractions were finished with a mechanical agitation of $30 \mathrm{~min}$. Samples treated with acidified hydroalcoholic solvents resulted in higher values of total phenolics and flavonoids and antioxidant activity. The extraction using acidified hydroethanol solvent was not affected by the time in the ultrasound. The contents of total phenolics and flavonoids were highly correlated with each other and with the antioxidant activity, especially when it was determined by the ferric-reducing antioxidant power method. Acidified hydroethanol solvent in ultrasound for $15 \mathrm{~min}$ is the most suitable extraction condition for the quantification of the contents of total phenolics and flavonoids in and the antioxidant activity of mate leaves.
\end{abstract}

Index terms: mate, polarity, polyphenols, solvents.

\section{Teores de compostos fenólicos totais e flavonoides e atividade antioxidante em folhas de Ilex paraguariensis}

Resumo - O objetivo deste trabalho foi avaliar diferentes solventes e tempos de extração de polifenóis com ultrassom, para quantificar os compostos fenólicos e flavonoides totais e a capacidade antioxidante em folhas de ervamate (Ilex paraguariensis). $\mathrm{O}$ experimento foi realizado em delineamento inteiramente casualizado, em arranjo fatorial $8 \times 3$ (solvente $\mathrm{x}$ tempo de extração). Os solventes foram água destilada e as soluções aquosas de etanol, acetona e metanol, acidificados ou não com ácido clorídrico, e os tempos de extração em banho ultrassônico foram de 15,30 e 45 min. As extrações foram concluídas com agitação mecânica de $30 \mathrm{~min}$. As amostras tratadas com solventes hidroalcoólicos acidificados apresentaram os maiores valores de compostos fenólicos e flavonoides totais e capacidade antioxidante. A extração com hidroetanol acidificado não foi afetada pelo tempo em ultrassom. Houve correlação entre os teores de compostos fenólicos e flavonoides totais e destes com a capacidade antioxidante, especialmente quando esta foi determinada pelo poder antioxidante redutor do íon ferro. $\mathrm{O}$ solvente hidroetanólico acidificado em ultrassom por 15 min é a condição de extração mais apropriada para a quantificação dos teores de compostos fenólicos totais e flavonoides e da capacidade antioxidante em folhas de erva-mate.

Termos para indexação: erva-mate, polaridade, polifenóis, solventes. 


\section{Introduction}

Mate (Ilex paraguariensis A. St.-Hil.) is a native tree species of Brazil, Argentina, and Paraguay, with high economic, social, and ecological importance. Mate products have recently raised interest due to their high content of phytochemicals, as phenolic acids, flavonoids, methylxanthines and saponins, as a new source of polyphenol-rich foods to prevent cardiovascular diseases (Cardozo Junior \& Morand, 2016).

The extraction of phytochemical compounds is one of the most critical steps in the research of natural products (Xynos et al., 2012) because the extraction efficiency depends on several parameters. Chemical composition and yield of the obtained extracts depend on the type of solvent. In many systems, extraction solvents are pure; however, when the aim is to improve the extraction power, it may be convenient to use mixtures (Alothman et al., 2009). Based on this principle, there are some studies on the use of solvents of varying polarity on vegetable matrices that aimed to identify different chemical classes present in the extracts produced with different solvents (Michiels et al., 2012). Since the solubility of polyphenols in a given solvent is a peculiar feature of the sample composition, there is a lack of a universal standard procedure and, consequently, a careful check of the extraction method for each natural source is necessary (Caetano et al., 2009). Solvents such as methanol, ethanol, and acetone can be used for the extraction of polyphenols (Naczk \& Shahidi, 2004; Michiels et al., 2012).

The development of extraction procedures allowing of the use of less aggressive solvents to the environment, and that can be used in smaller quantities, has been proposed as an alternative in the so-called green chemistry (Herrero et al., 2010). Toward this aim, conventional procedures have been replaced, or modified with the emergence of alternative methods, such as the extraction with supercritical or pressurized fluid (Xynos et al., 2012) and ultrasound-assisted extraction (Japón-Luján et al., 2006). Ultrasoundassisted extraction is a solid-liquid method in which the effects of ultrasound waves provide a greater penetration of the solvent inside the plant cells in a reduced time, with increased yields (Filgueiras et al., 2000), and reduction of solvent usage (Vilkhu et al., 2008). Ultrasound-assisted extraction has the advantage of decreasing the analyte extraction time mainly due to physical and chemical effects caused by the cavitation phenomenon (Soria \& Villamiel, 2010), yielding up two folds more soluble matter from mate leaves than the conventional infusion at the same temperature (Kotovicz et al., 2014). This method has been increasingly used in the extraction of compounds such as flavonoids (Sun et al., 2011), tannins, and phenolics (Aspé \& Fernández, 2011) because of its enhanced extraction of bioactive and food components at lower processing temperatures, and the possibility of replacing organic solvents by generally recognized as safe solvents (Vilkhu et al., 2008).

The evaluation of variables involved in the extraction process is very important for the production of plant extracts (Aspé \& Fernández, 2011). The majority of extractions of phenolic compounds in mate uses hot water as solvent, but only temperature and time have been evaluated (Pagliosa et al., 2010). Because it is a natural product, the great challenge for the extract processing industry is the standardization of polyphenol contents, which guarantees the performance of the industrialized product. In order to improve the product quality, it is important to develop an efficient and quick method for polyphenol quantification, aiming to standardize the extract production and the use of safe solvents of bioactive and food components. In addition, the definition of the method is essential for its quantification in a large number of mate genotypes, making it possible to know their genetic components, and to define the environmental conditions that maximize the phenolic and flavonoid contents and the antioxidant activity in leaves of mate.

The objective of this work was to evaluate different solvents and times in the ultrasound-assisted extraction of polyphenols, and to quantify the total phenolic and flavonoid contents and antioxidant activity of mate leaves.

\section{Materials and Methods}

The experiment was carried out in the center of plant breeding and propagation, Departamento de Fitotecnia (Plant Science Department), Universidade Federal de Santa Maria, Santa Maria, in the state of Rio grande do Sul, Brazil. The plant material (leaf samples) was collected from four adult genotypes of mate, cultivated in a wood in the Campus. Leaves were collected from the intermediate portion of all quadrants of each tree 
canopy, mixed, and dried in an oven with forced-air circulation at $65^{\circ} \mathrm{C}$, until reaching constant mass; the leaves were then ground in a micro mill MA-630 (Marconi, Piracicaba, SP, Brazil) until reaching the granulometry of commercial thick-grind mate, and used for separation of samples.

Total phenolics and flavonoids were extracted according to Tsai et al. (2014). The extraction conditions were optimized with type and composition of solvents and time of extraction in ultrasound. Extraction solvents were distilled water and aqueous solutions of ethanol, acetone, and methanol (70:30, v/v, solvent: water), and the same solvents acidified with $\mathrm{HCl} 6 \mathrm{M}$ at a 70:30:1 ratio (v/v/v, solvent: water: acid), totaling eight treatments of extraction solvents. The extractions were performed in an ultrasonic bath at 40 $\mathrm{kHz}$ (Ultra Sonic Clean, USC 1600 model) at a ratio of $2 \%$ (w/v, sample: solvent) for 15,30 , and $45 \mathrm{~min}$., in the dark at room temperature $\left(21 \pm 2^{\circ} \mathrm{C}\right)$. Then, the extracts were subjected to mechanical agitation in a microplate shaker MA562 (Marconi, Piracicaba, SP, Brazil) for $30 \mathrm{~min}$, filtered in filter paper, and placed in properly identified amber glass bottles, and stored at $-18^{\circ} \mathrm{C}$ until the analysis was performed. The experiment was an $8 \times 3$ (solvent $x$ time of extraction) factorial arrangement, in a randomized complete design, with three replicates, and readings in triplicates.

The total phenolic content produced in the mate extracts was the result of the oxidation-reduction reaction with Folin-Ciocalteu reagent, which reacts with hydroxyls present in polyphenols. The extracts were left in the dark, at room temperature for two hours. Absorbance readings were performed in triplicate, at $765 \mathrm{~nm}$ wavelength in a UV-visible spectrophotometer 200DM (HOMIS SF, São Paulo, SP, Brazil), according to Singleton \& Rossi (1965). The calibration curve was performed using gallic acid as standard, at of 0,10 , $20,30,40,50,60,70$, and $80 \mathrm{mg} \mathrm{L}^{-1}$. The content of phenolic compounds was obtained with the regression equation (content of phenolic compounds $=88.385 \times$ absorbance -2.9158 , with $\mathrm{R}^{2}=0.995$ ), expressed in milligrams of gallic acid equivalent per gram of dry mass (mg GAE g-1).

Flavonoid contents were analyzed by the colorimetric method (Zhishen et al., 1999). The absorbance readings were performed in triplicate in the above mentioned UV-visible spectrophotometer, at $510 \mathrm{~nm}$ wavelength. The flavonoid content was determined using a standard catechin (CAT) curve, at $0,50,100,150,200$, and $250 \mathrm{mg} \mathrm{L}^{-1}$, and the results were determined from a calibration curve (flavonoid content $=414.91 \times$ absorbance $\left.-1.7368, \mathrm{R}^{2}=0.995\right)$, expressed in milligrams of catechin equivalent per gram of dry mass (mg CAT g $\mathrm{g}^{-1}$ ).

The antioxidant activity was determined based upon the methods DPPH (2,2-diphenyl-1-picrylhydrazyl), ABTS [2,2'-azino-bis (3-ethylbenzothiazoline-6sulfonic acid)], and FRAP (ferric reducing antioxidant power) to attain more accurate quantification, as it is difficult to use one antioxidant activity of an unified standard method to evaluate plants (Du et al., 2009). The DPPH method is based on the reduction of $\mathrm{DPPH}(\bullet+)$ by antioxidants in the sample, producing a decrease of absorbance at $517 \mathrm{~nm}$, after remaining in the dark for 24 hours at room temperature (BrandWilliams et al., 1995). Absorbance readings were performed in triplicate, in the before mentioned UVvisible spectrophotometer against a blank control. The content of DPPH was calculated from a calibration curve (Trolox content $=0.0184 \times$ absorbance -0.1366 ; $\left.\mathrm{R}^{2}=0.985\right)$ using Trolox as standard, and the results were expressed ( $\mu \mathrm{mol} \mathrm{L} \mathrm{L}^{-1}$ Trolox $\mathrm{g}^{-1}$ of dry mass) as the antioxidant activity equivalent to Trolox.

The ABTS method is based on the generation of the ABTS $\bullet+$, which shows a blue-green color, via the reaction of ABTS with potassium persulfate and the addition of an antioxidant. ABTS $\bullet+$ is reduced to ABTS, promoting the loss of color (Re et al., 1999). Absorbance readings were performed after $6 \mathrm{~min}$ of reaction in triplicates at a $750 \mathrm{~nm}$ wavelength, in the previously mentioned UV-visible spectrophotometer. The synthetic antioxidant Trolox $\left(1 \mathrm{mmol} \mathrm{L}^{-1}\right)$ was used at $0,0.025,0.05,0.075,0.100$, and $0.150 \mathrm{mmol} \mathrm{L}^{-1}$ in ethanol for the calibration curve $(\%$ deactivation of absorbance corrected $=632.6 \times$ ability to reduce ABTS -+ in mmol L-1 Trolox L $\left.{ }^{-1}-2.5084, \mathrm{R}^{2}=0.995\right)$, and the results were expressed in ( $\mu \mathrm{mol}$ Trolox $\mathrm{g}^{-1}$ of dry mass) as the antioxidant activity equivalent to Trolox.

TheFRAP method is based on the directmeasurement of the activity of antioxidants (reducers) of the sample to reduce, in an acid medium ( $\mathrm{pH} 3.6$ ), the complex $\mathrm{Fe}^{3+} /$ tripyridyltriazine (TPTZ), to form $\mathrm{Fe}^{2+}$, of intense blue color, after incubation in water bath at $37^{\circ} \mathrm{C}$ for $30 \mathrm{~min}$ (Benzie \& Strain, 1996). The absorbance readings of samples were performed in triplicates in the previously mentioned UV-visible spectrophotometer, 
at $593 \mathrm{~nm}$ wavelength. Trolox $\left(1 \mathrm{mmol} \mathrm{L}^{-1}\right)$ was used as standard to construct a calibration curve (Trolox content $=22.759 \times$ absorbance $\left.-0.9019 ; \mathrm{R}^{2}=0.997\right)$, at $0,0.025,0.05,0.075,0.100$ and $0.150 \mathrm{mmol} \mathrm{L}^{-1}$ Trolox with results expressed in ( $\mu \mathrm{mol}$ Trolox $\mathrm{g}^{-1}$ of dry mass) as the antioxidant activity equivalent to Trolox.

Data were subjected to the analysis of variance, and means were compared by Tukey's test, at 5\% probability. Pearson's correlation analysis was run for total phenolic and flavonoid contents and antioxidant activity. The analyses were carried out with the Statistica software, version 7.0.

\section{Results and Discussion}

Total phenolic and flavonoid contents in extracts of mate leaves varied with solvent and time of extraction in ultrasound (Table 1). The samples treated with acidified hydroalcohol solvents showed higher values of total phenolic and flavonoid contents than nonacidified treatments, and their contents were not affected by the time of extraction with hydroethanol. Extraction in acidified hydroacetone (at 70\%) solvent for $45 \mathrm{~min}$ in ultrasound yielded the highest content of total phenolics, although there was no difference when time in ultrasound was reduced to $30 \mathrm{~min}$. For total flavonoid content, the time of extraction in ultrasound was found to be important for the acidified hydromethanol solvent (at 70\%), for which $45 \mathrm{~min}$ in ultrasound resulted in the highest content, with no difference from the same extraction time in acidified hydroacetone solvent (at 70\%).

Solvent acidification during the extraction process can increase the extraction of total phenolics, which was observed in the present study. This fact occurs because acidity favors the stability of the phenolic extraction target due to the non-release of the hydroxyl proton. Studies on vinification residues have also shown that the solvent acidification increases the extraction and, consequently, provides higher yield of total polyphenols (Lafka et al., 2007). These authors found a higher content of total polyphenols in vinification residues, when using an aqueous ethanol solvent 1:1, followed by methanol, ethanol, and acetone. The acidified ethanol (at 70\% solvent) resulted in the highest content of total phenolics and flavonoids in ultrasound-assisted extraction for $15 \mathrm{~min}$, with no differences when acetone and methanol were used as solvents in the same conditions (Table 1).

Table 1. Contents of total phenolics and flavonoids in mate leaves with the ultrasound-assisted extraction using different solvents and extraction times ${ }^{(1)}$.

\begin{tabular}{lccc}
\hline \multirow{2}{*}{ Solvent } & \multicolumn{3}{c}{ Ultrasound-assisted extraction time } \\
\cline { 2 - 4 } & $15 \mathrm{~min}$ & Total phenolics $\left(\mathrm{mg} \mathrm{GAE} \mathrm{g}^{-1}\right)$ & $45 \mathrm{~min}$ \\
Hydromethanol at $70 \%$ & $17.04 \pm 0.29 \mathrm{Cb}$ & $18.72 \pm 0.16 \mathrm{Bc}$ & $20.26 \pm 0.28 \mathrm{Ac}$ \\
Hydroethanol at $70 \%$ & $13.27 \pm 1.17 \mathrm{Bc}$ & $15.38 \pm 0.32 \mathrm{ABd}$ & $16.60 \pm 1.74 \mathrm{Ac}$ \\
Hydroacetone at $70 \%$ & $17.06 \pm 0.53 \mathrm{Cb}$ & $19.41 \pm 0.50 \mathrm{Bc}$ & $21.39 \pm 0.39 \mathrm{Ac}$ \\
Aqueous solution & $18.32 \pm 0.52 \mathrm{Ab}$ & $18.42 \pm 0.55 \mathrm{Ac}$ & $19.06 \pm 0.71 \mathrm{Abc}$ \\
Acidified hydromethanol $(70 \%)$ & $30.91 \pm 1.23 \mathrm{Aa}$ & $30.64 \pm 0.84 \mathrm{Ab}$ & $31.72 \pm 1.39 \mathrm{Ab}$ \\
Acidified hydroethanol $(70 \%)$ & $30.43 \pm 2.02 \mathrm{Aa}$ & $26.60 \pm 0.88 \mathrm{Ab}$ & $32.04 \pm 0.53 \mathrm{Ab}$ \\
Acidified hydroacetone $(70 \%)$ & $33.46 \pm 2.34 \mathrm{Ba}$ & $34.46 \pm 0.72 \mathrm{ABa}$ & $37.37 \pm 0.61 \mathrm{Aa}$ \\
Acidified in aqueous solution & $16.57 \pm 0.54 \mathrm{Abc}$ & $15.83 \pm 0.95 \mathrm{Ad}$ & $16.87 \pm 0.70 \mathrm{Ac}$ \\
\hline & & Total flavonoids (mg CAT g-1) & $19.21 \pm 0.65 \mathrm{Acd}$ \\
Hydromethanol at $70 \%$ & $16.80 \pm 0.53 \mathrm{Bb}$ & $18.64 \pm 0.20 \mathrm{Ab}$ & $17.27 \pm 0.56 \mathrm{Ad}$ \\
Hydroethanol at $70 \%$ & $13.85 \pm 0.33 \mathrm{Cc}$ & $15.57 \pm 0.40 \mathrm{Bc}$ & $21.05 \pm 0.90 \mathrm{Ac}$ \\
Hydroacetone at $70 \%$ & $16.39 \pm 1.32 \mathrm{Bbc}$ & $14.64 \pm 0.70 \mathrm{Bc}$ & $14.56 \pm 0.26 \mathrm{Ae}$ \\
Aqueous solution & $16.64 \pm 1.64 \mathrm{Abc}$ & $14.96 \pm 0.66 \mathrm{Ac}$ & $27.61 \pm 1.17 \mathrm{Aa}$ \\
Acidified hydromethanol $(70 \%)$ & $24.58 \pm 0.90 \mathrm{Ba}$ & $24.53 \pm 0.48 \mathrm{Ba}$ & $23.57 \pm 0.74 \mathrm{Ab}$ \\
Acidified hydroethanol $(70 \%)$ & $25.15 \pm 1.37 \mathrm{Aa}$ & $22.29 \pm 1.35 \mathrm{Aa}$ & $25.13 \pm 0.99 \mathrm{Aab}$ \\
Acidified hydroacetone $(70 \%)$ & $22.26 \pm 1.24 \mathrm{Ba}$ & $23.56 \pm 0.09 \mathrm{ABa}$ & $8.94 \pm 0.54 \mathrm{Af}$ \\
Acidified aqueous solution & $9.25 \pm 0.44 \mathrm{Ad}$ & $8.73 \pm 0.25 \mathrm{Ad}$ & \\
\hline
\end{tabular}

(1)Means followed by equal letters, lowercases in the columns and uppercases in the rows, do not differ by Tukey's test, at 5\% probability. 
The combination of an acidified solution and extraction in ultrasound resulted in higher contents of total phenolics and flavonoids in mate leaves, which may be indicative of the increased extraction activity of this method. Comparisons of the highest and the lowest values show that there was a 2.8 -fold increase for the contents of total phenolics and a 3.2-fold increase for flavonoids in mate leaves, which shows the importance of understanding the effect of different solvents and time of extraction in ultrasound to improve the technique and standardize the content quantifications of total phenolics and flavonoids. These results are in agreement with other reports showing the content variations of total phenolics and flavonoids in mate leaves and products. Solvent polarity, extraction method, and conditions affected the contents of total phenolics and flavonoids in mate tea extracts (Grujic et al., 2012). The extraction in distilled water at $90^{\circ} \mathrm{C}$ for $20 \mathrm{~min}$ showed differences of total phenolic contents of mate leaves, which increased with leaf age (Blum-Silva et al., 2015). Optimization of time and temperature extraction of commercial mate in distilled water resulted in $21.39 \mathrm{GAE} \mathrm{g}^{-1}$ total phenolics and 21.08 CAT g ${ }^{-1}$ flavonoids (Bassani et al., 2014). The extraction in distilled water resulted in 33.64 $\mathrm{GAE} \mathrm{g}^{-1}$ total phenolics and 8.80 $\mathrm{CAT} \mathrm{g}^{-1}$ flavonoids in commercial mate tea (Zielinski et al., 2014).

The antioxidant activity of the mate leaf extracts varied also with the extraction solvent and time of ultrasound-assisted extraction (Table 2). As expected, the evaluation methods (DPPH, ABTS, and FRAP) resulted in different antioxidant activities for each solvent and time of extraction. In the quantification of the antioxidant activity by DPPH, the acidified

Table 2. Antioxidant activity in mate leaves with the ultrasound-assisted extraction using different solvents and extraction times, quantified with the DPPH, ABTS, and FRAP methods ${ }^{(1)}$.

\begin{tabular}{|c|c|c|c|}
\hline \multirow[t]{2}{*}{ Solvent } & \multicolumn{3}{|c|}{ Ultrasound-assisted extraction time } \\
\hline & $15 \mathrm{~min}$ & $30 \mathrm{~min}$ & $45 \mathrm{~min}$ \\
\hline & \multicolumn{3}{|c|}{$\operatorname{DPPH}\left(\mu \mathrm{mol} \mathrm{L}^{-1}\right.$ Trolox g $\left.^{-1}\right)$} \\
\hline Hydromethanol at $70 \%$ & $2.99 \pm 0.80 \mathrm{Abc}$ & $4.03 \pm 0.43 \mathrm{Ab}$ & $4.16 \pm 0.10 \mathrm{Ab}$ \\
\hline Hydroethanol at $70 \%$ & $0.46 \pm 0.08 \mathrm{Bc}$ & $4.00 \pm 0.54 \mathrm{Ab}$ & $5.28 \pm 1.03 \mathrm{Ab}$ \\
\hline Hydroacetone at $70 \%$ & $4.94 \pm 0.59 \mathrm{Bb}$ & $6.80 \pm 0.39 \mathrm{Ab}$ & $6.89 \pm 0.31 \mathrm{Ab}$ \\
\hline Aqueous solution & $4.20 \pm 0.49 \mathrm{Ab}$ & $4.34 \pm 0.35 \mathrm{Ab}$ & $4.82 \pm 0.41 \mathrm{Ab}$ \\
\hline Acidified hydromethanol (70\%) & $14.62 \pm 1.09 \mathrm{Aa}$ & $15.02 \pm 0.91 \mathrm{Aa}$ & $14.46 \pm 1.44 \mathrm{Aa}$ \\
\hline Acidified hydroethanol (70\%) & $14.70 \pm 0.51 \mathrm{Aa}$ & $14.71 \pm 0.34 \mathrm{Aa}$ & $14.29 \pm 1.46 \mathrm{Aa}$ \\
\hline Acidified hydroacetone $(70 \%)$ & $14.36 \pm 1.44 \mathrm{Aa}$ & $15.37 \pm 0.34 \mathrm{Aa}$ & $13.35 \pm 0.22 \mathrm{Aa}$ \\
\hline \multirow[t]{2}{*}{ Acidified in aqueous solution } & $16.79 \pm 1.78 \mathrm{Aa}$ & $14.72 \pm 3.83 \mathrm{Aa}$ & $12.23 \pm 1.77 \mathrm{Aa}$ \\
\hline & \multicolumn{3}{|c|}{ ABTS $\left(\mu\right.$ mol L L $^{-1}$ Trolox $\left.\mathrm{g}^{-1}\right)$} \\
\hline $70 \%$ hydromethanol & $69.94 \pm 7.32 \mathrm{Babc}$ & $81.13 \pm 0.84 \mathrm{Aba}$ & $89.53 \pm 4.28 \mathrm{Aa}$ \\
\hline $70 \%$ hydroethanol & $58.80 \pm 0.70 \mathrm{Bbc}$ & $67.07 \pm 6.09 \mathrm{Bbc}$ & $78.34 \pm 3.02 \mathrm{Aab}$ \\
\hline $70 \%$ hydroacetone & $72.75 \pm 0.85 \mathrm{Bab}$ & $86.35 \pm 2.61 \mathrm{Aa}$ & $88.08 \pm 5.92 \mathrm{Aa}$ \\
\hline Aqueous solution & $57.87 \pm 0.49 \mathrm{Ac}$ & $60.57 \pm 5.33 \mathrm{Ac}$ & $59.76 \pm 5.16 \mathrm{Ac}$ \\
\hline Acidified hydromethanol (70\%) & $81.69 \pm 2.49 \mathrm{Aa}$ & $79.34 \pm 3.00 \mathrm{Aa}$ & $81.58 \pm 2.18 \mathrm{Aab}$ \\
\hline Acidified hydroethanol (70\%) & $76.09 \pm 2.13 \mathrm{Aa}$ & $77.32 \pm 4.16 \mathrm{Aab}$ & $78.86 \pm 7.15 \mathrm{Aab}$ \\
\hline Acidified hydroacetone $(70 \%)$ & $73.26 \pm 9.86 \mathrm{Aab}$ & $62.29 \pm 5.59 \mathrm{Ac}$ & $72.15 \pm 2.46 \mathrm{Abc}$ \\
\hline \multirow[t]{2}{*}{ Acidified in aqueous solution } & $34.60 \pm 7.24 \mathrm{Ad}$ & $38.64 \pm 1.52 \mathrm{Ad}$ & $29.18 \pm 9.59 \mathrm{Ad}$ \\
\hline & \multicolumn{3}{|c|}{ FRAP $\left(\mu \mathrm{mol} \mathrm{L}^{-1}\right.$ Trolox g $\left.^{-1}\right)$} \\
\hline Hydromethanol at $70 \%$ & $135.8 \pm 1.76 \mathrm{Ccd}$ & $152.2 \pm 5.17 \mathrm{Bd}$ & $166.5 \pm 3.00 \mathrm{Ab}$ \\
\hline Hydroethanol at $70 \%$ & $111.7 \pm 1.70 \mathrm{Be}$ & $138.9 \pm 0.22 \mathrm{Ae}$ & $136.6 \pm 7.25 \mathrm{Ae}$ \\
\hline Hydroacetone at $70 \%$ & $150.0 \pm 3.91 \mathrm{Bc}$ & $165.8 \pm 2.79 \mathrm{Bc}$ & $285.8 \pm 9.41 \mathrm{Ab}$ \\
\hline Aqueous solution & $133.8 \pm 4.55 \mathrm{Ad}$ & $114.1 \pm 5.24 \mathrm{Bf}$ & $112.1 \pm 4.08 \mathrm{Bf}$ \\
\hline Acidified hydromethanol (70\%) & $253.8 \pm 11.20 \mathrm{Ab}$ & $258.3 \pm 4.44 \mathrm{Ab}$ & $282.8 \pm 4.31 \mathrm{Ab}$ \\
\hline Acidified hydroethanol $(70 \%)$ & $257.6 \pm 3.15 \mathrm{Ab}$ & $254.3 \pm 1.69 \mathrm{Ab}$ & $256.3 \pm 2.12 \mathrm{Ac}$ \\
\hline Acidified hydroacetone $(70 \%)$ & $280.2 \pm 1.61 \mathrm{Ca}$ & $307.1 \pm 7.60 \mathrm{Ba}$ & $339.9 \pm 3.86 \mathrm{Aa}$ \\
\hline Acidified in aqueous solution & $109.0 \pm 4.94 \mathrm{Be}$ & $135.0 \pm 0.42 \mathrm{Ae}$ & $133.2 \pm 2.49 \mathrm{Ae}$ \\
\hline
\end{tabular}

(1)Means followed by equal letters, lowercases in the columns and uppercases in the rows, do not differ by Tukey's test, at 5\% probability. DPPH, 2,2-diphenyl-1-picrylhydrazyl; ABTS, 2,2'-azino-bis (3-ethylbenzothiazoline-6-sulfonic acid); FRAP, ferric reducing antioxidant power. 
extractants resulted in higher values, with no difference between solvents and times in ultrasound-assisted extraction. In vinification residues, ethanol extracts showed higher-antioxidant activity than methanol and acetone based upon DPPH (Lafka et al., 2007), whose differences were not found in the present work even using different time of ultrasound-assisted extraction. When evaluated by ABTS, the highest value obtained for antioxidant activity $\left(89.53 \mu \mathrm{mol} \mathrm{L} \mathrm{L}^{-1}\right.$ Trolox $\left.\mathrm{g}^{-1}\right)$ was found at $70 \%$ hydromethanol solution for $45 \mathrm{~min}$ in ultrasound. This treatment did not differ from the treatments with hydroethanol at $70 \%$, hydroacetone at $70 \%$, and acidified hydromethanol (70\%) and hydroethanol $(70 \%)$, all for $45 \mathrm{~min}$ in ultrasound. The time of extraction affected the nonacidified hydromethanol (70\%), hydroethanol, and hydroacetone treatments. FRAP quantification of the antioxidant activity showed the highest value in mate leaves with acidification of hydroacetone at $70 \%$. In this extraction solvent, increasing the time in ultrasound resulted in higher-antioxidant activity, and the highest value was $333.9 \mu \mathrm{mol} \mathrm{L}^{-1}$ Trolox $\mathrm{g}^{-1}$ at $45 \mathrm{~min}$.

Differences in the antioxidant activity were already found for solvent polarity, method and conditions of extractions (Grujic et al., 2012), and analytical procedures (Peres et al., 2013). The solvents used in the present study affected the antioxidant activity, since the type of solvent and its polarity can affect the transfer of hydrogen atoms and electrons, which directly influences the antioxidant activity (Rockenbach et al., 2007). With the DPPH method, the acidified solvents showing the greatest extraction provided from 24 to 34 -fold greater antioxidant activity than that found with the solvent giving the lowest extraction (Table 2). A lower variation among solvents was found with ABTS and FRAP methods. For ABTS, extraction at $70 \%$ hydromethanol was 3.1-fold higher than that found with acidified aqueous solution, both for $45 \mathrm{~min}$ in ultrasound. A similar variation was found for the FRAP method between the acidified hydroacetone $(70 \%)$ for $45 \mathrm{~min}$ in ultrasound and the acidified aqueous solution for $15 \mathrm{~min}$ in ultrasound. The FRAP method also resulted in the greatest antioxidant activity in mate leaves, which is in agreement with Zielinski et al. (2014) that found higher-antioxidant activity with FRAP than with DPPH in commercial mate tea.

Total phenolics and flavonoids were highly correlated $(r=0.852)$ to each other and also with the antioxidant activity, depending on the method of quantification (Table 3). The highest correlations between total phenolics and antioxidant activity were obtained with DPPH and FRAP, whereas for flavonoid contents they were obtained with ABTS and FRAP. Therefore, the antioxidant activity determined with FRAP was correlated with the contents of total phenolics and flavonoids. These high correlations are of great importance, as they show that total phenolics produced are mostly flavonoids associated with the antioxidant activity, especially when quantified by the FRAP method. Some of these correlations were already found in other studies. Total phenolics was also correlated with the antioxidant activity determined with the DPPH method in mate leaves (Blum-Silva et al., 2015). The contents of total phenolics and flavonoids were correlated with the antioxidant activity quantified with FRAP and DPPH in commercial mate tea (Zielinski et al., 2014). Flavonoid contents and antioxidant activity were correlated in commercial mate (Bassani et al., 2014).

A delineation of suitable extraction conditions (solvents and time in ultrasound) is provided by the present work for the determination of total phenolics and flavonoids and the antioxidant activity with the FRAP method in mate leaves. The ultrasoundassisted extraction is an alternative technology to advance the "green chemistry", enabling the use of ethanol, an inexpensive solvent that is less aggressive to the environment and that is easy to use. The optimized condition was the acidified solvent at $70 \%$ hydroethanol and the extraction in ultrasound for 15 min. The content quantifications of total phenolics

Table 3. Pearson correlations for the contents of total phenolics and flavonoids and antioxidant activity, quantified with the DPPH, ABTS, and FRAP methods, in mate leaves, with ultrasound-assisted extractions using different solvents and extraction times.

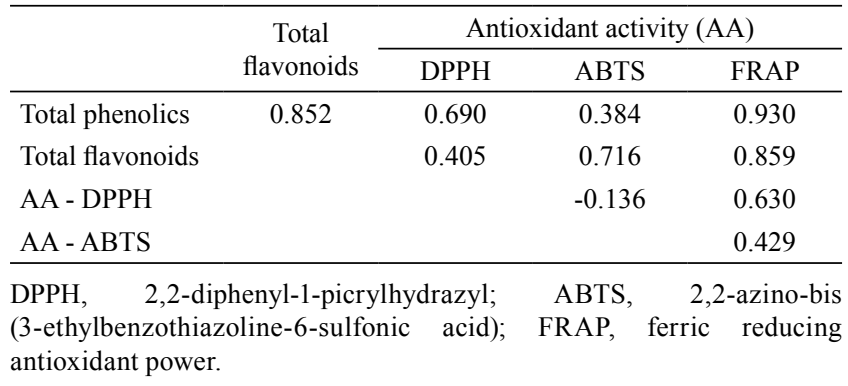


and flavonoids associated with the antioxidant activity open the opportunity for generating relevant datasets for the selection of genotypes with higher contents of these bioactive compounds, and for determining the environmental conditions that maximize their production in mate plants.

\section{Conclusion}

The acidified solvent with hydroethanol in ultrasound for $15 \mathrm{~min}$ is the most suitable extraction condition for the content quantifications of total phenolics and flavonoids and the antioxidant activity of mate leaves.

\section{References}

ALOTHMAN, M.; BHAT, R.; KARIM, A.A. Antioxidant capacity and phenolic content of selected tropical fruits from Malaysia, extracted with different solvents. Food Chemistry, v.115, p.785788, 2009. DOI: https://doi.org/10.1016/j.foodchem.2008.12.005.

ASPÉ, E; FERNÁNDEZ, K. The effect of different extraction techniques on extraction yield, total phenolic, and anti-radical capacity of extracts from Pinus radiata Bark. Industrial Crops and Products, v.34, p.838-844, 2011. DOI: https://doi.org/10.1016/j.indcrop.2011.02.002.

BASSANI, D.C.; NUNES, D.S.; GRANATO, D. Optimization of phenolics and flavonoids extraction conditions and antioxidant activity of roasted yerba-mate leaves (Ilex paraguariensis A. St.Hil., Aquifoliaceae) using response surface methodology. Anais da Academia Brasileira de Ciências, v.86, p.923-933, 2014. DOI: https://doi.org/10.1590/0001-3765201420130019.

BENZIE, I.F.F.; STRAIN, J.J. The ferric reducing ability of plasma (FRAP) as a measure of "antioxidant power": The FRAP assay. Analytical Biochemistry, v.239, p.70-76, 1996. DOI: https://doi. org/10.1590/0001-376520142013001910.1006/abio.1996.0292.

BLUM-SILVA, C.H.; CHAVES, V.C.; SCHENKEL, E.P.; COELHO, G.C.; REGINATTO, F.H. The influence of leaf age on methylxanthines, total phenolic content, and free radical scavenging capacity of Ilex paraguariensis aqueous extracts. Revista Brasileira de Farmacognosia, v.25, p.1-6, 2015. DOI: https://doi.org/10.1016/j.bjp.2015.01.002.

BRAND-WILLIAMS, W.; CUVELIER, M.E.; BERSET, C. Use of a free radical method to evaluate antioxidant activity. Food Science and Technology, v.28, p.25-30, 1995. DOI: https://doi.org/10.1016/S0023-6438(95)80008-5.

CAETANO, A.C. da S.; MELO, E.A.; LIMA, V.L.A.G.; MACIEL, M.I.S.; ARAÚJO, C.R. de. Extração de antioxidantes de resíduos agroindustriais de acerola. Brazilian Journal of Food Technology, v.12, p.155-160, 2009. DOI: https://doi.org/10.4260/ bjft2009800900006.

CARDOZO JUNIOR, E.L.; MORAND, C. Interest of mate (Ilex paraguariensis A. St.-Hil.) as a new natural functional food to preserve human cardiovascular health - A review. Journal of Functional Foods, v.21, p.440-454, 2016. DOI: https://doi.org/10.1016/j.jff.2015.12.010.

DU, G.; LI, M.; MA, F.; LIANG, D. Antioxidant capacity and the relationship with polyphenol and vitamin $\mathrm{C}$ in Actinidia fruits. Food Chemistry, v.113, p.557-562, 2009. DOI: https://doi.org/10.1016/j.foodchem.2008.08.025.

FILGUEIRAS, A.V.; CAPELO, J.L.; LAVILLA, I.; BENDICHO, C. Comparison of ultrasound-assisted extraction and microwaveassisted digestion for determination of magnesium, manganese and zinc in plant samples by flame atomic absorption spectrometry. Talanta, v.53, p.433-441, 2000. DOI: https://doi.org/10.1016/ S0039-9140(00)00510-5.

GRUJIC, N.; LEPOJEVIC, Z.; SRDJENOVIC, B.; VLADIC, J.; SUDJI, J. Effects of different extraction methods and conditions on the phenolic composition of mate tea extracts. Molecules, v.17, p.2518-2528, 2012. DOI: https://doi.org/10.3390/ molecules17032518.

HERRERO, M.; PLAZA, M.; CIFUENTES, A.; IBÁÑEZ, E. Green processes for the extraction of bioactives from Rosemary: chemical and functional characterization via ultra-performance liquid chromatography-tandem mass spectrometry and in-vitro assays. Journal of Chromatography A, v.1217, p.2512-2520, 2010. DOI: https://doi.org/10.1016/j.chroma.2009.11.032.

JAPÓN-LUJÁN， R.; LUQUE-RODRÍGUEZ， J.M.; LUQUE DE CASTRO, M.D. Dynamic ultrasound-assisted extraction of oleuropein and related biophenols from olive leaves. Journal of Chromatography A, v.1108, p.76-82, 2006. DOI: https://doi.org/10.1016/j.chroma.2005.12.106.

KOTOVICZ, V.; WYPYCH, F.; ZANOELO, E.F. Pulsed hydrostatic pressure and ultrasound assisted extraction of soluble matter from mate leaves (Ilex paraguariensis): experiments and modeling. Separation and Purification Technology, v.132, p.19, 2014. DOI: https://doi.org/10.1016/j.seppur.2014.04.036.

LAFKA, T.-I.; SINANOGLOU, V.; LAZOS, E.S. On the extraction and antioxidant activity of phenolic compounds from winery wastes. Food Chemistry, v.104, p.1206-1214, 2007. DOI: https://doi.org/10.1016/j.foodchem.2007.01.068.

MICHIELS, J.A.; KEVERS, C.; PINCEMAIL, J.; DEFRAIGNE, J.O.; DOMMES, J. Extraction conditions can greatly influence antioxidant capacity assays in plant food matrices. Food Chemistry, v.130, p.986-993, 2012. DOI: https://doi.org/10.1016/j. foodchem.2011.07.117.

NACZK, M.; SHAHIDI, F. Extraction and analysis of phenolics in food. Journal of Chromatography A, v.1054, p.95-111, 2004. DOI: https://doi.org/10.1016/j.chroma.2004.08.059.

PAGLIOSA, C.M.; VIEIRA, M.A.; PODESTÁ, R.; MARASCHIN, M.; ZENI, A.L.B.; AMANTE, E.R.; AMBONI, R.D. de M.C. Methylxanthines, phenolic composition, and antioxidant activity of bark from residues from mate tree harvesting (Ilex paraguariensis A. St. Hil.). Food Chemistry, v.122, p.173-178, 2010. DOI: https://doi.org/10.1016/j.foodchem.2010.02.040.

PERES, R.G.; TONIN, F.G.; TAVARES, M.F.M.; RODRIGUEZAMAYA, D.B. HPLC-DAD-ESI/MS identification and quantification of phenolic compounds in Ilex paraguariensis 
beverages and on-line evaluation of individual antioxidant activity. Molecules, v.18, p.3859-3871, 2013. DOI: https://doi.org/10.3390/molecules18043859.

RE, R.; PELlEGRINI, N.; PROTEGGENTE, A.; PANNALA, A.; YANG, M.; RICE-EVANS, C. Antioxidant activity applying an improved ABTS radical cation decolorization assay. Free Radical Biology \& Medicine, v.26, p.1231-1237, 1999. DOI: https://doi.org/10.1016/S0891-5849(98)00315-3.

ROCKENBACH, I.I.; SILVA, G.L. da; RODRIGUES, E.; GONZAGA, L.V.; FETT, R. Atividade antioxidante de extratos de bagaço de uva das variedades Regente e Pinot Noir (Vitis vinifera). Revista do Instituto Adolfo Lutz, v.66, p.158-163, 2007.

SINGLETON, V.L.; ROSSI, J.A. Colorimetry of total phenolics with phosphomolybdic-phosphotungstic acid reagents. American Journal of Enology and Viticulture, v.16, p.144-158, 1965.

SORIA, A.C.; VILLAMIEL, M. Effect of ultrasound on the technological properties and bioactivity of food: a review. Trends in Food Science \& Technology, v.21, p.323-331, 2010. DOI: https://doi.org/10.1016/j.tifs.2010.04.003.

SUN, Y.; LIU, Z.; WANG, J. Ultrasound-assisted extraction of five isoflavones from Iris tectorum Maxim. Separation and Purification Technology, v.78, p.49-54, 2011. DOI: https://doi.org/10.1016/j.seppur.2011.01.017.

TSAI, C.-C.; CHOU, C.-H.; LIU, Y.-C.; HSIEH, C.-W. Ultrasoundassisted extraction of phenolic compounds from Phyllanthus emblica $\mathrm{L}$. and evaluation of antioxidant activities. International Journal of Cosmetic Science, v.36, p.471-476, 2014. DOI: https://doi.org/10.1111/ics.12143.

VILKHU, K.; MAWSON, R.; SIMONS, L.; BATES, D. Applications and opportunities for ultrasound assisted extraction in the food industry - a review. Innovative Food Science and Emerging Technologies, v.9, p.161-169, 2008. DOI: https://doi.org/10.1016/j.ifset.2007.04.014.

XYNOS, N.; PAPAEFSTATHIOU, G.; PSYCHIS, M.; ARGYROPOULOU, A.; ALIGIANNIS, N.; SKALTSOUNIS, A.-L. Development of a green extraction procedure with super/ subcritical fluids to produce extracts enriched in oleuropein from olive leaves. Journal of Supercritical Fluids, v.67, p.89-93, 2012. DOI: https://doi.org/10.1016/j.supflu.2012.03.014.

ZHISHEN, J.; MENGCHENG, T.; JIANMING, W. The determination of flavonoid contents in mulberry and their scavenging effects on superoxide radicals. Food Chemistry, v.64, p.555-559, 1999. DOI: https://doi.org/10.1016/S03088146(98)00102-2.

ZIELINSKI, A.A.F.; HAMINIUK, C.W.I.; ALBERTI, A.; NOGUEIRA, A.; DEMIATE, I.M.; GRANATO, D. A comparative study of the phenolic compounds and the in vitro antioxidant activity of different Brazilian teas using multivariate statistical techniques. Food Research International, v.60, p.246-254, 2014. DOI: https://doi.org/10.1016/j.foodres.2013.09.010. 